\title{
Resource alignment in the category management of builders' merchants
}

\author{
Daniel Ellström and Jakob Rehme
}

\section{Linköping University Post Print}

\section{Tweet}

N.B.: When citing this work, cite the original article.

This is an electronic version of an article published in:

Daniel Ellström and Jakob Rehme, Resource alignment in the category management of builders' merchants, 2016, International Review of Retail Distribution \& Consumer Research, (26), 1, 55-74.

International Review of Retail Distribution \&amp; Consumer Research is available online at informaworld ${ }^{\mathrm{TM}}$ :

http://dx.doi.org/10.1080/09593969.2015.1120681

Copyright: Taylor \& Francis (Routledge): SSH Titles

http://www.routledge.com/

Postprint available at: Linköping University Electronic Press

http://urn.kb.se/resolve?urn=urn:nbn:se:liu:diva-121507 


\title{
Resource alignment in the category management of builders' merchants
}

\begin{abstract}
Previous retailer-supplier research reports both positive and negative collaboration outcomes. Resource alignment, or how collaborating actors' resources affect each other, is a concept that has been brought forward to explain when collaboration increases performance. As the category management of builders' merchants involves actors with different sets of resources, the resource alignment framework can be used to better understand the outcomes of collaboration in category management. The aim of this paper is to explore resource alignment among actors involved in the category management of builders' merchants. The paper is based on interviews with top managers in Swedish builders' merchants. Complementary and supplementary resources held by the involved actors are identified for four distinguished category management activities. Resources needed to further improve the business are also identified. Three propositions are formulated, explaining how supplementary and complementary resources are interrelated and how the situation influences the need for supplementary resources. The description of resource alignment supports retailers and their suppliers concerning how to assign roles and responsibilities in category management activities. While the retailers themselves are often well equipped to manage pricing and inventory management, the supplier can support assortment and marketing management.
\end{abstract}

Keywords - resource alignment, retailer supplier collaboration, category management, builders' merchants

Paper type - Case Study 


\section{Introduction}

Retailers acknowledge the benefit of managing product categories in collaboration with their suppliers (Harris and McPartland, 1993; Dupre and Gruen, 2004; Aastrup, Grant and Bjerre, 2007). Several examples from retail practice show how suppliers have been successfully assigned as category captains, with the responsibility of managing an entire product category (cf. Subramanian et al., 2010; Kurtuluş et al., 2014). The benefit of supplier collaboration relies on the assumption that suppliers understand market trends within their own categories (Gruen and Shah, 2000; Kurtuluş et al., 2014) and that category expertise is shared between retailers and suppliers (Harris and McPartland, 1993). However, some authors are hesitant towards the benefits associated with supplier collaboration in category management (e.g. Desrochers, Gundlach and Foer, 2003; Bandyopadhyay, Rominger and Basaviah, 2009), and others suggest that supplier collaboration is only suitable for some of the retailer's categories (Kurtulus and Toktay, 2005).

Integrating suppliers in category development is however often mentioned as an essential part of category management (Harris and McPartland, 1993; Gruen and Shah, 2000; Dhar, Hoch and Kumar, 2001; Dupre and Gruen, 2004). In some cases, suppliers can be granted the role of a category captain; that is, they function as management advisors that aim to grow sales in the category (Dupre and Gruen, 2004; Bandyopadhyay, Rominger and Basaviah, 2009; Subramanian et al., 2010; Gooner, Morgan and Perreault, 2011). A subsequent and important question for retailers is the role that different actors should take in category management. Aastrup et al. (2007) discussed this issue in terms of value creation and appropriation between supplier and retailer, and that close interaction and trust are important for a well-functioning category. Category management can include several actors (Bandyopadhyay, Rominger and Basaviah, 2009), and consequently, it depends on individual actors' resources (Aastrup, Grant and Bjerre, 2007). Therefore, category management can benefit from further analysis of the resources held by the involved actors.

The resource alignment framework has been used for understanding collaborations between actors, and emanates from a resource-based view, where resources are categorized as complementary, supplementary, wasteful or surplus (Das and Teng, 2000). Complementary and supplementary resources are both described as useful in the alliance, but complementary resources are dissimilar, whereas supplementary resources are similar (e.g. Song et al., 2005; Lin, Yang and Arya, 2009). To better understand resource alignment, this paper looks at how the resources of suppliers and retailers contribute to the retailers' category management.

The collaboration conditions of category management vary in different kinds of retailing. To understand how the resources involved can shape the actors' roles, this study looks at builders' merchants (BMs) and their suppliers. Here, the suppliers understand their products, while the BMs are far more knowledgeable about their customers. In addition, the BM stores are often managed separately as franchise holders or members of a group, where the resources of the store differ greatly from those of the central management. Therefore, the division of roles and responsibilities between the suppliers, the stores and the BM central management can contribute to the understanding of supply chain resource alignment in category management. The aim of this paper is to explore resource alignment among actors involved in 
the category management of builders' merchants. This exploration is intended to result in propositions concerning: (a) when supplementary and complementary resources are needed in the category management of builders' merchants, and (b) how supplementary and complementary resources interrelate and depend on each other in the category management of builders' merchants.

The remainder of the article is structured as follows. First, a theoretical investigation addresses the activities included in category management, Das and Teng's (2003) model of resource alignment and its effect on performance. Second, the methodology and the interviews with top managers in BM central management are described. Third, the results of the interviews are presented and supported with illustrative quotes. Lastly, the conclusions and contributions of the paper are discussed.

\section{Category management activities}

Category management is a concept that emerged in academic retailing literature during the 1990s. The meaning given to category management differs slightly in previous literature, but there is a common understanding that product categories are managed as strategic business units in category management, and retailers who adopt it do so to maximize each product category's profitability (Harris and McPartland, 1993; Basuroy, Mantrala and Walters, 2001). The alternative to category management is often described as brand-oriented or brandcentered management (Basuroy, Mantrala and Walters, 2001; Dupre and Gruen, 2004; Kurtuluş and Toktay, 2011), where supplier brands are managed separately and with limited consideration to the consequences for competing brands within the same categories. With categories as business units, category management also entails integrating supply-anddemand-related decisions such as procurement and merchandising (Harris and McPartland, 1993; Basuroy, Mantrala and Walters, 2001) instead of handling them separately. Category management also implies a focus on customer value (Dhar, Hoch and Kumar, 2001; Desrochers, Gundlach and Foer, 2003; Dupre and Gruen, 2004; Aastrup, Grant and Bjerre, 2007; Bandyopadhyay, Rominger and Basaviah, 2009), which can be considered a logical consequence of managing categories as separate business units and integrating supply-anddemand-related decisions.

Category management is often described as a specific process that some retailers have adopted and some have not (e.g. Dussart, 1998; Cachon and Kök, 2007; Bandyopadhyay, Rominger and Basaviah, 2009). What is included differs between authors, but a common view is that categories, instead of brands, are used as the strategic business units. Category management is also associated with ideas on how to work as a retailer. For example, close collaborations with suppliers (Basuroy, Mantrala and Walters, 2001; Dupre and Gruen, 2004; Aastrup, Grant and Bjerre, 2007) and strong customer focus (Harris and McPartland, 1993; Dussart, 1998; Gruen and Shah, 2000) are often mentioned as being parts of category management. Category management, however, can be implemented to a varying extent, and retailers' use of brands or categories as strategic business units is not always apparent. This view of category management as an approach applied by all retailers is also reflected by other authors (e.g. Dhar, Hoch and Kumar, 2001; Gooner, Morgan and Perreault, 2011). Therefore, 
in this paper category management is considered to be an array of activities that all retailers do to a varying extent.

In order to describe the activities that constitute category management in a way that includes the currently existing view of the phenomenon, the previous literature on category management has to be examined. While most authors agree that the aim of category management is to improve different aspects of category performance, there are discrepancies concerning what activities and decisions should be included in category management (see Table 1). As almost all articles on category management mention activities associated with category management, it is surprising that so few articles support their statements with references to previous research and discrepancies among what activities to include still exist. Based on previous research, as provided in Table 1, we discern four distinct activities that consist category management: assortment management, pricing, marketing and inventory management.

Table 1: Overview of previous literature regarding its view on the activities included in category management

\begin{tabular}{|c|c|c|c|c|}
\hline Author(s) & Assortment & Pricing & Marketing & $\begin{array}{l}\text { Inventory } \\
\text { management }\end{array}$ \\
\hline Chen et al. (1999) & $\bar{X}$ & & $\begin{array}{l}\mathrm{X} \text { (shelf space } \\
\text { allocation) }\end{array}$ & \\
\hline $\begin{array}{l}\text { Gruen and Shah } \\
(2000)\end{array}$ & $\mathrm{X}$ & $\mathrm{X}$ & $\begin{array}{l}\mathrm{X} \text { (promotion and } \\
\text { placement) }\end{array}$ & $\begin{array}{l}\mathrm{X} \text { (timely } \\
\text { deliveries) }\end{array}$ \\
\hline Dhar et al. (2001) & $\mathrm{X}$ & $\mathrm{X}$ & $\begin{array}{l}\mathrm{X} \text { (advertising and } \\
\text { promotions) }\end{array}$ & \\
\hline Basuroy et al. (2001) & & $\mathrm{X}$ & $\mathrm{X}$ (merchandising) & $\mathrm{X}$ (procurement) \\
\hline $\begin{array}{l}\text { Desrochers et al. } \\
(2003)\end{array}$ & $\bar{X}$ & $\mathrm{X}$ & $\begin{array}{l}X \text { (merchandising, } \\
\text { shelf space } \\
\text { allocation, } \\
\text { promotional } \\
\text { schedules) }\end{array}$ & \\
\hline $\begin{array}{l}\text { Dupre and Gruen } \\
\text { (2004) }\end{array}$ & $\mathrm{X}$ & $\mathrm{X}$ & & \\
\hline $\begin{array}{l}\text { Campo and } \\
\text { Gijsbrechts (2005) }\end{array}$ & $\bar{X}$ & $\mathrm{X}$ & $\begin{array}{l}\mathrm{X} \text { (shelf } \\
\text { management and } \\
\text { promotion) }\end{array}$ & $\begin{array}{l}\mathrm{X} \text { (stock-out } \\
\text { management) }\end{array}$ \\
\hline Larson (2005) & $\mathrm{X}$ & & $\begin{array}{l}\mathrm{X} \text { (shelf } \\
\text { arrangement) }\end{array}$ & \\
\hline
\end{tabular}




\begin{tabular}{|c|c|c|c|c|}
\hline $\begin{array}{l}\text { Cachon and Kök } \\
\text { (2007) }\end{array}$ & $\mathrm{X}$ & $\mathrm{X}$ & & \\
\hline $\begin{array}{l}\text { Lindblom et al. } \\
(2009)\end{array}$ & $\mathrm{X}$ & $\mathrm{X}$ & $\begin{array}{l}\mathrm{X} \text { (promotion and } \\
\text { space management) }\end{array}$ & $\begin{array}{l}\mathrm{X} \text { (inventory } \\
\text { replenishment) }\end{array}$ \\
\hline $\begin{array}{l}\text { Bandyopadhyay et al. } \\
\text { (2009) }\end{array}$ & & $\mathrm{X}$ & $\begin{array}{l}\mathrm{X} \text { (display and } \\
\text { promotion) }\end{array}$ & \\
\hline $\begin{array}{l}\text { Holweg and Teller } \\
\text { (2009) }\end{array}$ & $\mathrm{X}$ & & $\mathrm{X}$ (promotion) & \\
\hline $\begin{array}{l}\text { Subramanian et al. } \\
(2010)\end{array}$ & $\mathrm{X}$ & $\mathrm{X}$ & $\begin{array}{l}\mathrm{X} \text { (promotion and } \\
\text { shelf space } \\
\text { assignments) }\end{array}$ & \\
\hline Gooner et al. (2011) & $\mathrm{X}$ & & $\begin{array}{l}\mathrm{X} \text { (promotional } \\
\text { schedules, } \\
\text { advertising, } \\
\text { merchandising) }\end{array}$ & $\begin{array}{l}\mathrm{X} \text { (logistical } \\
\text { activities) }\end{array}$ \\
\hline $\begin{array}{l}\text { Kurtulus and Toktay } \\
\text { (2011) }\end{array}$ & $\mathrm{X}$ & $\mathrm{X}$ & $\mathrm{X}$ (shelf placement) & \\
\hline $\begin{array}{l}\text { Hubner and Kuhn } \\
\text { (2012) }\end{array}$ & $\mathrm{X}$ & & $\mathrm{X}$ (shelf facing) & $\begin{array}{l}\text { X (replenishment } \\
\text { decisions) }\end{array}$ \\
\hline Kurtulus et al. (2014) & $\mathrm{X}$ & & $\begin{array}{l}\mathrm{X} \text { (signage and } \\
\text { visual hints) }\end{array}$ & \\
\hline
\end{tabular}

An activity that is mentioned in almost all articles that try to specify category management activities is assortment choice. This activity aims to determine which products to sell within the category, and is therefore an obvious part of category management. A second clearly defined activity in category management is that of pricing. In addition to selecting an assortment, all retailers must determine at what prices to sell their products, and this is also often included as a category management activity. The remaining category management activities that are mentioned in previous research are less consistent, and many activities that are mentioned strongly resemble one another. To limit the number of activities included, and to make the activities as mutually exclusive as possible, I describe the remaining activities as either related to marketing or to inventory management. Several authors mention different forms of shelf space allocation, or what product to place where in the store, as a part of category management (Chen et al., 1999; Gruen and Shah, 2000; Desrochers, Gundlach and Foer, 2003; Campo and Gijsbrechts, 2005; Larson, 2005; Bandyopadhyay, Rominger and Basaviah, 2009; Lindblom et al., 2009; Subramanian et al., 2010; Kurtuluş and Toktay, 2011; Hübner and Kuhn, 2012). As seen in Table 1, this is classified as a marketing activity, as it 
intends to make the products in the store look more attractive for the customer. Promotional activities, advertising and merchandising are also activities mentioned in previous literature that are classified as marketing. In addition, signage and visual hints, mentioned by Kurtulus et al. (2014), are classified as marketing activities.

The remaining activities that previous articles have included in category management can be seen as part of inventory management. This include timely deliveries (Gruen and Shah, 2000), procurement (Basuroy, Mantrala and Walters, 2001), stock-out management (Campo and Gijsbrechts, 2005), inventory replenishment (Lindblom et al., 2009), logistical activities (Gooner, Morgan and Perreault, 2011) and replenishment decisions (Hübner and Kuhn, 2012). Inventory management is here defined as the tasks of delivering the right products, in the right quantities and at the right time. Category management has been viewed as the demand-side strategies of efficient consumer response (Dupre and Gruen, 2004; Lindblom et al., 2009), and some authors argue that supply-side activities, such as inventory management, are not part of category management (e.g. Dupre and Gruen, 2004; Subramanian et al., 2010). Other authors do not strictly follow this distinction, and consider category management as a broader management philosophy that can also include supply-oriented activities (e.g. Basuroy, Mantrala and Walters, 2001; Gooner, Morgan and Perreault, 2011; Hübner and Kuhn, 2012). In this view, category management entails both supply and demand side activities, rendering it a role similar to that of a business unit (Basuroy, Mantrala and Walters, 2001) - a view also adopted in this article. Thus, inventory management is included in category management, even though it is primarily a supply-side activity. The category management activities and the decisions they entail are summarized in Table 2.

Table 2: Category management activities and the resulting CM decisions

\begin{tabular}{l|l}
\hline $\begin{array}{l}\text { Category Management } \\
\text { Activities }\end{array}$ & Category Management Decisions \\
\hline Assortment activities & $\begin{array}{l}\text { Decisions on what categories to carry, and what products } \\
\text { and variants to sell within a category }\end{array}$ \\
\hline Pricing activities & $\begin{array}{l}\text { Decisions about pricing strategy, and the pricing of } \\
\text { individual articles }\end{array}$ \\
\hline Marketing activities & $\begin{array}{l}\text { Decisions about advertising, promotions and strategies for } \\
\text { merchandising, as well as space allocations and shelf } \\
\text { placements etc, }\end{array}$ \\
\hline $\begin{array}{l}\text { Inventory management } \\
\text { activities }\end{array}$ & $\begin{array}{l}\text { Decisions about logistics activities, such as stock-out } \\
\text { management, replenishment tactics, order frequency etc. }\end{array}$ \\
\hline
\end{tabular}

\section{Resource alignment}

While the resource-based view has primarily been used to analyze the competitive advantage of individual firms (Dyer and Singh, 1998), several authors have recognized that firms need to search outside the boundaries of the firm to access the resources they need (Håkansson and Snehota, 1989; Dyer and Singh, 1998; Das and Teng, 2000; Ireland, Hitt and Vaidyanath, 2002; Adegbesan, 2009; Lin, Yang and Arya, 2009; Squire et al., 2009). To acknowledge the emphasis on dyad or network resources as the source of competitive advantage, the extended resource-based view of the firm is brought forward as a complement to the traditional 
resource-based view (Mathews, 2003; Squire, Cousins and Brown, 2006; Arya and Lin, 2007). In this vein, two motives have been suggested for creating strategic alliances: to access the resources of others, or to develop internal resources (Das and Teng, 2000). In this paper, the focus is on the access to resources that follow from alliances. The resource-based view suggests that more value can be created when resources are pooled within an alliance, and competitive advantage in alliances is based on the effective integration of valuable resources by the alliance partners (Das and Teng, 2000; Lin, Yang and Arya, 2009). Grant and BadenFuller (2004) argued that knowledge access engenders strategic alliances.

According to Das and Teng (2000), the critical test of the resources available in an alliance is whether there is alignment of the resources; they described the resources of firms engaged in an alliance as either performing or nonperforming, and similar or dissimilar (see Table 3). In this typology, resource similarity is the extent to which resources are comparable in type and amount (Das and Teng, 2000). Resources can be of the same kind as those held by the alliance partner (for example, technological) but still be considered dissimilar if the resources are different in nature (Das and Teng, 2003). In other words, similarity refers to type and nature of the resource, but not to what kind of resource. What is actually meant by type, nature or kind is unfortunately not developed in detail. Resources utilization, or the performance of resources, is determined by the degree to which the resources can be used to achieve the goals of the alliance. The differentiation between performing and nonperforming resources is often implicit in research, as the latter are largely disregarded (Das and Teng, 2000, 2003). The division of resources based on similarity and utilization creates the following resource alignment typology: supplementary, complementary, surplus and wasteful.

Table 3: Resource alignment (Das and Teng, 2000)

\begin{tabular}{l|l|l|}
\hline Resources & Performing & Non-performing \\
\hline Similar & Supplementary & Surplus \\
\hline Dissimilar & Complementary & Wasteful \\
\hline
\end{tabular}

The alignment of resources is proposed to affect alliance performance (Das and Teng, 2000, 2003). Supplementary and complementary resources have a positive effect on the collective strength in the alliance, but are not related to inter-firm conflicts. Surplus resources may decrease inter-firm conflict, while wasteful resources may increase inter-firm conflict. High collective strength and low inter-firm conflict correlate to alliance performance (Das and Teng, 2003).

Complementary resources are far more researched than supplementary resources (Das and Teng, 2000; Wittmann, Hunt and Arnett, 2009), and complementary resources are claimed to be more important for alliance performance and partner selection (Doh, 2000; Hitt et al., 2000; Lin, Yang and Arya, 2009; Wittmann, Hunt and Arnett, 2009). Stuart (2000) showed that small firms in partnerships with experienced firms perform better than other small firms. Hitt (2000) also wrote that firms in emerging markets seek partners with financial and 
technical expertise, while firms in developed markets seek partners with geographical expertise, indicating a search for partners with complementary resources. Lambe et al. (2002) and Wittman et al. (2009) claimed that complementary resources lead to idiosyncratic resources that, in turn, create alliance performance.

However, Wittman et al. (2009) also included the relational factors commitment, trust and communication to explain alliance financial performance. With a resource perspective, it can be argued that supplementary resources are needed to build trust, commitment and open communication. Sarkar et al. (2001) hypothesized that project and strategic performance increase when partners have complementary resources and when there is cultural and operational compatibility. In relation to Das and Teng's (2000) typology, their operationalization of complementary resources mainly distinguishes the performing aspects of the resources instead of their dissimilarity. Therefore, it is possible Sarkar et al. (2001) measured both supplementary and complementary resources in their data collection. The cultural and operational compatibility in the framework of Sarkar et al. (2001) can also be understood as a need for supplementary resources. This supports the assumption that supplementary resources have an effect on dyad performance. The hypotheses of Sarkar et al. (2001) are only partially supported, thus suggesting further investigation of supplementary and complementary resources.

Since firms can acquire resources from each other, they seek partners with resources that they need (Gulati, Nohria and Zaheer, 2000; Ireland, Hitt and Vaidyanath, 2002). Stuart (2000) showed that small firms in partnerships with experienced ones acquire a competitive advantage. Findings by Doh (2000) and Lin et al. (2009) similarly indicated that alliances with firms with complementary resources increase performance. Hitt (2000) also noted that firms in emerging markets seek partners with financial and technical expertise, while firms in developed markets seek partners with geographical expertise, indicating a search for partners with complementary resources. Lambe et al. (2002) and Wittman et al. (2009) claimed that complementary resources lead to idiosyncratic resources that, in turn, boost the financial performance in the alliance. Few studies contradict the necessity of having complementary resources. The findings concerning alliances are likely transferable to other kinds of buyersupplier relationships, but there is still a need to explore how complementary and supplementary resources are perceived by retailers and their suppliers. Moreover, the relation between complementary and supplementary resources has been given limited attention in the above-mentioned research.

\section{Methodology}

Qualitative research on resource alignment has struggled with the operationalization of resource-based constructs, and it has often been handled by using secondary data proxies (Das and Teng, 2000). Wang and Zajoc (2007) and Lin et al. (2009) studied resource complementarity quantitatively, and studied similarity using SIC industry codes as a measure. Harrison et al. (1991) used the slightly more sophisticated level of R\&D intensity, capital intensity, administrative intensity and debt intensity as alignment proxies. Apparently, 
similarity is difficult to quantify; a qualitative case study can avoid the uncertainty associated with using these proxies.

Das and Teng (2000) also distinguished between performing and nonperforming resources; that is, similar resources may or may not be useful depending on whether they are supplementary or surplus. In addition, dissimilar resources may be either complementary or wasteful, depending on their usability. Making this distinction requires a data collection method that considers respondents' beliefs and insights.

\section{Context}

This study targets Swedish BMs that mainly sell to professional customers, as opposed to DIY retailers that primarily attract private consumers. Professional customers are more specific in their demands, and this increases the merchants' product knowledge needs. In this kind of retailing, the relations between customers and the stores are also important, which increases the need for the resources held by stores. As several actors are involved in the BMs' category management, this context is suitable to study when exploring resource alignment. BM managers also perceive their own industry to lag behind other kinds of retailing. Therefore, it is interesting to compare BM development to other kinds of retailing, using a resource-based perspective to understand industry developments.

Sweden's four biggest BMs targeting professional customers are included in the study. One is a BM chain, while the other three are independent BMs, meaning that the stores are owned by several separate firms, but are members in a voluntary BM group overseeing activities such as marketing, finance and IT. The way responsibilities are shared between the central management and the individual stores differs from firm to firm. More details on the BMs in this study are provided in Table 4.

Table 4: The BMs included in this study. Data from 2012

\begin{tabular}{|l|l|l|c|c|}
\hline & $\begin{array}{l}\text { Independent or } \\
\text { chain }\end{array}$ & $\begin{array}{l}\text { Turnover } \\
\text { (in kSEK) }\end{array}$ & $\begin{array}{c}\text { Number of } \\
\text { stores }\end{array}$ & $\begin{array}{l}\text { Profit margin } \\
\text { (in \%) }\end{array}$ \\
\hline BM 1 & Independent & $6,900,000$ & 120 & 2.9 \\
\hline BM 2 & Independent & $5,700,000$ & 123 & 2.7 \\
\hline BM 3 & Chain & $5,000,000$ & 66 & 6.4 \\
\hline BM 4 & Independent & $3,800,000$ & 190 & 2.4 \\
\hline
\end{tabular}

\section{Data collection}

To have an understanding of the industry and the challenges they face, an initial round of interviews was conducted with a category purchasing manager, a product manager and a sales manager in BM 3, as well as with the purchasing director in another BM that is not part of the main study for this paper. Initial interviews were also made with the sales division of a BM supplier, in order to possess a better understanding of their current and potential role in category management. 
After the initial round of interviews, four final interviews were made with managing directors or purchasing directors. These interviews, together with secondary data in the form of homepages, presentation material and product folders, are the main sources for the data analysis. The directors are responsible for decisions on how to include suppliers in their businesses, and therefore have a good understanding of the reasoning behind these choices. The directors were perceived to have good insights into the resources with which the suppliers could contribute and what resources they held themselves. The interviews lasted between one and two hours. All interview quotes have been confirmed and translated to English.

A data collection challenge was that the processes and activities first had to be explained prior to describing the needed resources. Therefore, the interview guide only contained general questions about (1) how the activities are carried out and what their difficulties are, (2) what resources are needed for excelling, and (3) the existence of these resources among the involved actors. This is in line with the ideas of Day (1994), who suggested that capabilities can be identified by mapping a firm's process activities. The challenge for the interviewer is to pick up on difficulties and ask what is needed to overcome them.

The interviews aimed to capture both the current situation and the intended development of category management. The different scenarios' performance or profitability outcomes were not specifically emphasized. Instead, the respondents' descriptions of what challenges they faced were used to understand how resources contribute to perceived performance.

\section{Data analysis}

Transcripts of the interviews have been used to analyze the four category management activities, and to identify performing resources that the involved actors currently hold as well as performing resources that are needed to improve the category management. The resources identified could be both tangible and intangible, and were interpreted during the interviews together with the respondents, based on their explanations of what is needed to carry out the category management activities. The discussions and interpretations during the four interviews were then cross-analyzed to identify performing resources that were mentioned in at least two of the interviews. Some specific resources were grouped together into broader categories. For example, knowledge of local customer demand is a resource that consists of different aspects of this knowledge that were mentioned in the interviews. In total, fourteen resources were identified as performing in the category management activities. The resources were then classified as complementary or supplementary, based on an analysis of whether they were held by both the supplier and the BM.. For each category management activity, different statements were coded based on their indication of useful resources held and further resource needs. The statements were also coded based on whether the resources were indicated to be supplementary or complementary.

\section{The category management of four builders' merchants}

The empirical findings describe the resources needed by the involved actors when conducting category management, divided into the four category management activities, assortment. As there is a difference between the needed resources the actors currently hold and the currently 
unavailable resources needed for improving business performance, these are described separately.

\section{Assortment choice}

The responsibility for assortment decisions is held by the stores, but they are influenced both from the BM central management and from the suppliers.

According to the interviews, the supplier, the stores and the BM central management hold dissimilar assortment management resources that can all be useful; therefore, the resources are potentially complementary. The quotes below indicate that stores have close relations with their customers and the BM central management knows aggregated demand and can structure assortment management, while the supplier knows how products fit together.

We have product councils for each product category with at least one representative from each of our seven regions. Their role is to bring customer input, trends and regional differences from the stores to the product manager... The product manager makes decisions based on store representatives' thoughts in combination with what he statistically sees in the system. The stores then get information from the product manager on what assortment suits them. (BM3)

It is often the supplier who knows what is going on in his assortment. (BM2)

There is both competence and experience among suppliers that should be capitalized on... The suppliers have unique product knowledge. (BM4)

The complementarity of the knowledge and capability resources is exemplified in the following quote:

[In our assortment management] we constantly start from the local market, and if a store is passionate about window installations, that is not a problem for the central organization. We just have to adapt. (BM4)

The interviewees did, as seen in the following quotes, express a need for both the stores and the suppliers to broaden their understanding of customer value in order for the stores and the suppliers to contribute to assortment management.

We contact our suppliers and are open about what we want. "We invite you to join this journey." If we have a transparent plan for what to do and if both are willing to invest heavily, then we get there. Then we start to talk about how we conduct retailing together, and there are some suppliers who are ready for that, but so far they are quite few. (BM4)

The worst thing I know is hearing from a store that "we do not carry that item because no customer asks for it." "Ok, but if you place it in the shelf, do you think it will sell then?" "I have no idea." (BM2)

The BM's have an opinion on how customer value is created in retailing. Therefore, suppliers need a view of customer value that resembles the BM's view, if the BMs should allow the 
supplier to "conduct retailing together" with them. Similarly, the stores need a shared view on customer value to make the final decision on what assortment to keep. With this shared view, the three actors' unique resources can complement each other and be used with an aim to increase customer value. As the view of customer value needs to be shared, it is a supplementary resource. Without this shared understanding, the supplier's product expertise and the stores' knowledge of local demand cannot be fully exploited, making them wasteful rather than complementary resources. Fawcett and Magnan (2001) stated that buyers and suppliers need a "common vision" if they should be able to establish an effective integration. A shared view on customer value is likely an important aspect of this common vision.

\section{Pricing}

Store prices are often determined by the stores themselves, and are based on a combination of purchasing prices and market prices. The suppliers only indirectly influence the pricing decisions of the BMs through their selling prices. According to the directors in the interviews, the supplier's role in the pricing decision is strictly regulated, due to anti-trust concerns. These issues are discussed more in-depth elsewhere (e.g. Desrochers, Gundlach and Foer, 2003). The BM groups that organize independent BMs are, for similar anti-trust reasons, not allowed to stipulate prices. However, one director of a BM group does suggest that an increased central management influence over pricing would improve the business. In the BM chain, prices are determined centrally.

The resources needed for pricing are dissimilar between the three kinds of actors. The suppliers' knowledge is limited to the production costs that should be reflected in their selling price. Because of this, and because of anti-trust concerns, supplier resources can be considered as wasteful. This is also illustrated in the following quote:

Suppliers should not be involved in pricing. Their role is to produce and develop products. (BM4)

The stores understand local circumstances and the demands of customers, as illustrated by the Managing Director in BM1:

The stores have responsibility for the pricing decisions... Customers ask for better prices on some products, so it is important that the person responsible for pricing knows what the customers demand. (BM1)

The BM central management often collects data from competitors' websites, and therefore has an understanding of price suitability. Through its size, the central management also has the resources necessary to create templates and IT support for the frequently used rebate systems. The need for IT systems and templates is explained by the following quotes:

What is required is good supporting IT systems that enable management of the gigantic assortment of products. (BM2)

We supply the stores with templates for customer contracts that are adapted to different kinds of customers. We also have indexed price levels in the different templates. (BM3) 
Because the resources from both the stores and the central management are needed to make the pricing decision, the resources are complementary. This complementarity is also explained in the following quote:

The IT system provides initial values for determining prices... The stores are then allowed to adjust prices from this level, either by determining a margin or by basing it on market prices. We provide the preconditions. We provide the entire orchestra, but they have to play the instruments themselves depending on what they want it to sound like. (BM2)

In the interviews, some BMs mentioned a need to increase understanding of how one product's pricing can affect the entire business. Inspired by other retailing sectors, respondents argued for a very competitive pricing of staple items, whose prices are often compared by customers. Other, slower-selling products would then be given a higher margin. However, this way of pricing is perceived to require a developed understanding of pricing's effect on sales in general. As the respondents perceive the BM central management to be best suited for acquiring this resource, this would also require central management to increase its pricing decision control. The ability to understand pricing's effect on sales could be a complementary resource. The need for this kind of market knowledge is illustrated in the following quote:

Market knowledge is required in the different categories. This means that competitors, customers, and suppliers are known. We have to understand this to be able to sell. (BM3)

Regarding pricing, the empirical findings do not indicate any need for resource similarity. As a result, the necessary store and central management resources are complementary, as they cover knowledge on different aggregation levels.

\section{Marketing}

Marketing efforts are carried out differently in the different BMs, but some common marketing practices can be found. Suppliers often provide product information, while central management often coordinates larger marketing campaigns, but with varied store involvement. Education provided to customers on how to use the products is also an important part of marketing for which suppliers are responsible.

Successful marketing efforts require an understanding of products and customers. Much like assortment management, the actors need complementary resources. The suppliers need to know their products, the stores need to know the local customers, and the BM central management coordinates the marketing efforts across the stores and uses its size to provide support to the stores. The roles of suppliers and BM central management in marketing are shown in the following quotes:

The suppliers contribute with education of our employees and our customers in product knowledge, how the products can be used, building technique, etc. (BM3) 
When a new product is introduced it might be better if the producer speaks for that product. (BM2)

We provide guidelines centrally. "If you make an ad, make in in this way." Then we do collective campaigns, a collective webpage, digital tools to use locally with customers, educations, etc. (BM1)

We negotiate centrally with suppliers so our stores have about 50-60 pages to choose from, then we have a web-based tool where the store picks eight pages that they want to include in their brochure. When they have chosen pages they also get to choose the selling prices of the products. Then they get the brochure printed with their own logo. Then all the customers in the store's database get text messages and e-mails with the offers of the store. The stores also get their own homepage, where their chosen products and prices are shown. This is entirely generated by the IT system. This can only be achieved when you unite and do something collaboratively. (BM4)

To improve marketing efforts, the suppliers need to expand their product knowledge to include customer-value understanding. Many suppliers know the technical characteristics of their products, but do not know what the customers value in the products or how this value should be communicated to customers. As with assortment management, there is a need for the supplier and the BMs to hold a supplementary resource in terms of customer-value knowledge. The suppliers and the BMs are responsible for different marketing activities, and customer value has to permeate all of them. The suppliers' lack of customer-value knowledge is illustrated below:

Suppliers need to improve their education of our employees and our customers. [Suppliers] have to learn how to use the products. (BM1)

Suppliers sometimes, in their education, tend to delve in details and become too technical. Then they have to see the big picture and ask what the arguments are for the customer. Talk so the customer understands. What is the surplus value for the customer? (BM3)

This is the new role for the suppliers - to manage the knowledge surrounding the products. It is much more efficient than the old role, where suppliers were supposed to convince the stores to include their products in the assortment. That is not needed today. Now they need to handle knowledge instead of a price list. Suppliers are still mentally adapting to this shift. (BM2)

The actors hold complementary marketing resources; however, to better exploit these resources, there is a need for the supplier and the BM to obtain supplementary resources regarding the understanding of customer value. Mainly, the suppliers are perceived to need to improve communication about their products. 


\section{Inventory management}

Usually, stores order products from their suppliers when their inventory levels are running low, and the suppliers then make a delivery. To limit distribution costs, stores order several products from the same supplier at once and the suppliers coordinate drops to several nearby BMs at the same time. The BM chain has a distribution center, and one of the buying groups is planning to set up a distribution center as well. With these centers the suppliers can deliver larger volumes, while the stores can order products from many suppliers at once. The actual responsibility for inventory management differs between the BMs. In the BM chain, central management orders 70 to 80 percent of the products. In the buying groups, however, the stores are still responsible for ordering their own products.

To plan their production, suppliers need to forecast future demand. Seasonal variations - and trends, to some extent - greatly affect BM sales. Therefore, the suppliers and BMs benefit from anticipating these changes. According to the interviewees, the stores' main resource in inventory management is their inventory level awareness. With accurate data systems, the inventory levels can also be monitored by BM central management. The managers interviewed for this study perceive that the BM central management can anticipate future demand and coordinate inventory management to a further extent than stores, which further increases their suitability to order products to stores. As long as the stores and the BM central management are able to combine their respective resources, they are complementary. For the buying groups, the BM central managements' resources become wasteful, as they are not involved in the inventory management. The need to incorporate customer behavior in the inventory management, and the BM central management's perceived ability to do so, are highlighted in the quotations below:

As a supplier an even production is very important. That can only happen if our replenishment follows customer demand. The more information we collect about customer needs and behaviors, the less peaks and dips there will be in the production. The inefficient structure we currently have will only work as long as the customer is willing to pay for it. (BM4)

We make forecasts and are able to make them quite accurate. Suppliers know what they sell to us, but they do not know what we are selling. They do not know if variations depend on changes in sales in the market or if we make adjustments in our inventory levels. For that reason, suppliers are provided with forecasts when needed. (BM3)

When stores are responsible for ordering, the BM central managements' resources are not used to their full potential: even though they are probably best suited to coordinate orders in a cost-efficient manner and forecast future demand, they do not use this resource at all. The need to include BM central management in inventory management can be interpreted from the following quotes:

It is a matter of efficiency to let two persons in the central management manage all procurement instead of having 65 stores manage it themselves. (BM3) 
In this industry we have huge excess stocks. Our stores have an inventory turnover ratio of less than two times per year. (BM4)

Increasing central management's control over ordering requires IT support systems, so that sales and inventory levels in the stores can be properly tracked. The BM central managements' resources then become complementary resources. In order for the suppliers to also take advantage of the central management's future demand estimating expertise, the BM central management needs to communicate this demand to their suppliers. Currently, the supplier and BM IT systems are often not sufficiently sophisticated to enable such developments. Therefore, if inventory management should be efficiently managed, supplementary IT resources need to be held by both the BMs and their suppliers. This need is articulated in the following quotes:

Our great improvement potential is to make more stores work with inventory levels... To do so, we need education, discipline, a strong will and simplifications in our current IT system. (BM1)

Some suppliers of commodity products, often foreign ones, do not have the possibility to manage EDI. (BM3)

Knowledge of future demand and inventory level is not supplementary, as the inventory management is not carried out in collaboration between the store and the BM central management. Depending on who is responsible for the activity, the other actor will have nonperforming, surplus resources in this area. When the store is responsible for ordering, the BM central management's ability to coordinate orders is a nonperforming, wasteful resource. When the central management is responsible for ordering, this resource is complementary. The ability to predict future demand is currently needed both by the supplier and by the actor responsible for ordering products; therefore, this resource is complementary. The BM central management can at least obtain resources that make them most suitable to take responsibility over orders and forecasts. Store expertise in this area would be a surplus resource. When it comes to IT maturity, the suppliers' and the BMs' resources supplement each other, as they need systems that can communicate.

\section{Category management and resources alignment}

This study highlights the actors' utilization of resources to be able to carry out category management activities. This is structured based on the four category management activities identified in the literature review. For the different category management activities, the involved actors hold different complementary resources, as summarized in

Table 5. 
Table 5: Summary of complementary resources in the four activities of category management, held by the BM and the supplier

\begin{tabular}{|c|c|c|}
\hline \multirow{2}{*}{$\begin{array}{l}\text { Category } \\
\text { Management } \\
\text { Activities }\end{array}$} & \multicolumn{2}{|l|}{ Complementary Resources } \\
\hline & Builders Merchants & Supplier \\
\hline $\begin{array}{l}\text { Assortment } \\
\text { activities }\end{array}$ & $\begin{array}{l}\text { Stores know local customer demands, } \\
\text { Central management knows aggregated } \\
\text { demand }\end{array}$ & $\begin{array}{l}\text { Supplier knows products, and availability of } \\
\text { different varieties as well as the fit between } \\
\text { different products. }\end{array}$ \\
\hline Pricing activities & $\begin{array}{l}\text { Stores: know local market. } \\
\text { Central management partly knows supply chain } \\
\text { costs and market prices, and can provide } \\
\text { support in rebate systems. }\end{array}$ & $\begin{array}{l}\text { Supplier: knows general market and general } \\
\text { price levels, as well as specific cost drivers for } \\
\text { different articles }\end{array}$ \\
\hline $\begin{array}{l}\text { Marketing } \\
\text { activities }\end{array}$ & $\begin{array}{l}\text { Stores: know local customer demands, } \\
\text { Central management knows aggregated } \\
\text { demand }\end{array}$ & $\begin{array}{l}\text { Supplier: knows products and the general } \\
\text { application of these products }\end{array}$ \\
\hline $\begin{array}{l}\text { Inventory } \\
\text { management } \\
\text { activities }\end{array}$ & $\begin{array}{l}\text { Stores: Know how much is in stock. } \\
\text { Central management: Knows changes in } \\
\text { demand (due to ad campaigns or changes in } \\
\text { stock levels). Can also benefit from economies of } \\
\text { scale in inventory management. }\end{array}$ & $\begin{array}{l}\text { Supplier: knows general market consumption as } \\
\text { well as in-bound supply of raw material }\end{array}$ \\
\hline
\end{tabular}

This study also revealed a demand for resources that the supplier and the BM do not currently possess. The most important resource developments desired by the respondents are summarized in Table 6. As the table illustrates, the desired resource developments differ for the different category management activities.

Table 6. Resource development for improved category management. 


\begin{tabular}{|c|c|c|}
\hline \multirow{2}{*}{$\begin{array}{l}\text { Category } \\
\text { Management } \\
\text { Activities }\end{array}$} & \multicolumn{2}{|l|}{ Resource Development } \\
\hline & Complementary Resources & Supplementary Resources \\
\hline $\begin{array}{l}\text { Assortment } \\
\text { activities }\end{array}$ & & $\begin{array}{l}\text { Supplier: needs to improve knowledge of } \\
\text { customers and customer value for a common } \\
\text { understanding of assortment decisions }\end{array}$ \\
\hline Pricing activities & $\begin{array}{l}\text { BM Central management can develop } \\
\text { knowledge of relative pricing and how } \\
\text { pricing of one product can affect the } \\
\text { entire business. }\end{array}$ & \\
\hline $\begin{array}{l}\text { Marketing } \\
\text { activities }\end{array}$ & & $\begin{array}{l}\text { Supplier: needs to improve knowledge of } \\
\text { customers and customer value. Suppliers also } \\
\text { need to adjust to the IT maturity in the BMs. }\end{array}$ \\
\hline $\begin{array}{l}\text { Inventory } \\
\text { management } \\
\text { activities }\end{array}$ & $\begin{array}{l}\text { BM Central management: needs to } \\
\text { further develop IT support systems }\end{array}$ & $\begin{array}{l}\text { Suppliers: need to develop Electronic Data } \\
\text { Interchange and be able to use forecasts and } \\
\text { production plans. }\end{array}$ \\
\hline
\end{tabular}

\section{Conclusion and discussion}

This paper explores resource alignment among actors involved in builders' merchants' category management, which emphasizes considering both supplementary and complementary resources held by the involved actors. Supplementary resources are important when it comes to IT adaptation and actors' understanding of customer value. Complementary resources are important for the specific expertise held by the different actors: the supplier should be the expert on products, the BM central management should be the expert in retailing and aggregated-level marketing, and the stores should be experts in understanding the local circumstances and building relationships with customers.

To enable capitalizing on the supplier's complementary resources, the supplier is also required to hold some supplementary resources; without them, the supplier's unique resources are partly nonperforming, and therefore wasteful (cf. Das and Teng, 2000). For example, the suppliers are required to increase their understanding of customer value (a supplementary resource) for their product expertise to influence the BMs' assortment decision, as seen in Table 6. This conclusion contrasts with other resource alignment works that have marginalized or disregarded supplementary resources (e.g. Harrison et al., 2001; Adegbesan, 2009; Lin, Yang and Arya, 2009). This view can also provide important literature input, since supply chain integration is closely related to resource alignment (Narasimhan and Kim, 2002; van der Vaart and van Donk, 2008). However, the role of supplementary resources, is not stressed in integration literature. The suggested interrelation between supplementary and complementary resources is formulated in the proposition below:

Proposition 1: If suppliers that are integrated in BM category management have supplementary resources, it is more likely that their dissimilar resources are complementary rather than wasteful.

This study does not give definitive answers regarding why supplementary resources are mentioned as important in the relationships between suppliers and BM central managements, 
but not in the relationships between stores and BM central managements. Within marketing research, trust is perceived to be a crucial factor for explaining alliance success (Morgan and Hunt, 1994); these ideas are also adopted in resource alignment research (e.g. Lambe, Spekman and Hunt, 2002; Wittmann, Hunt and Arnett, 2009). Therefore, a possible explanation is the higher degrees of trust within the BMs compared to the supplier relationship. The stores and the BM central management have made long-term investments in their relationship and are highly interdependent. In this situation, the store and the BM central management can divide responsibilities to a further extent, and do not need to share resources. In the relationships with the suppliers, trust is lower and relationship vulnerability is higher. Therefore, opportunistic behavior risk (c.f. Williamson, 1991) is higher. This is also supported by Gruen and Shah (2000), who claimed that it is difficult for retailers to recognize supplier opportunism in category management. The actors then need to have similar resources in order to ensure that the other actor does not act opportunistically.

For example, the suppliers' marketing roles are currently limited to educating store employees - and sometimes the customers. If the suppliers would share in the BMs' understanding of customer value (a supplementary resource), they could be given more responsibility in educating customers and other marketing activities. Another (supplementary) resource needed by the suppliers is IT maturity, which could grant them more responsibility in marketing activities.. If trust were higher between a supplier and a BM, they could share responsibility for the marketing activities to a larger extent. Without this mutual trust, the responsibility devolves to one of the actors. In the example of customer education, the supplier can be fully responsible for some programs, while the BM is fully responsible for others. Therefore, they need similar resources, as both have to explain product characteristics and customer value in their educational programs. With higher trust, they would be able to take responsibility for different educational parts: the supplier for product characteristics and the BM for the customer value. This leads to proposition 2:

Proposition 2: For a supplier that is integrated in the category management of a BM, the need for supplementary resources is higher when trust between the supplier and the BM is low.

The supplementary resource need, however, is only present for responsibilities that affect both the supplier and the BM. In this case, the pricing decision does not directly influence the supplier, and then the resources of the supplier complement those of the BM, even though they lack supplementary resources. This is formulated in proposition 3:

Proposition 3: The need for supplementary resources among BMs and suppliers is higher when the resources are needed for category management activities for which the actors have a shared responsibility.

In addition to the propositions, this paper makes two contributions to category management research. First, a description and a modularization of category management into four distinct activities are provided. Second, this paper illustrates how resource alignment can be used to assess how suppliers and stores can contribute to category management. 
First, this article provides a theoretical description of category management in relation to previous literature and the definition of four category management activities. Previous literature contains surprisingly few reviews of which activities other authors include in category management; this is often taken for granted (e.g. Chen et al., 1999; Dhar, Hoch and Kumar, 2001; Cachon and Kök, 2007), although these assumptions can vary significantly. In this paper, category management is considered an approach that all retailers have adopted to a varying extent. Category management consists of the four activities of assortment choice, pricing, marketing, and inventory management.

Second, this article illustrates how the resource alignment framework introduced by Das and Teng (2000) can be used to assess how suppliers and stores can contribute to category management. As noted in the introduction, previous category management research does not agree on when and how suppliers should be included. By adopting the resource alignment framework, new insights are provided with regard to when and how the resources of suppliers and local stores can be used to improve category management. The specific resources needed in the four category management activities can be seen in Table 7. For the assortment and marketing activities, the supplier can potentially provide useful knowledge about its products, while the BM stores should know the local market and how the market demands affects assortment and marketing activities. The BM and the supplier also need a shared view on customer value if the BM should trust the supplier to make suggestions that will increase customer value, as perceived by the BM. For pricing activities, the supplier can provide recommended prices based on the costs incurred by the different products, whereas the BM has to adapt these suggestions to suit the market prices. Finally, inventory management activities are mainly reliant on information communication systems that enable the supplier to share its production plans and the BM to share sales data and forecasted future demand.

Table 7: Complementary and supplementary resources needed in the category management activities of builders' merchants

\begin{tabular}{|c|c|c|c|}
\hline \multirow{2}{*}{$\begin{array}{l}\text { Category } \\
\text { Management } \\
\text { Activities }\end{array}$} & \multicolumn{2}{|c|}{ Complementary Resources } & \multirow{2}{*}{$\begin{array}{l}\text { Supplementary Resources } \\
\text { Joint }\end{array}$} \\
\hline & BM & Supplier & \\
\hline $\begin{array}{l}\text { Assortment } \\
\text { activities }\end{array}$ & $\begin{array}{l}\text { Local customer } \\
\text { demand }\end{array}$ & $\begin{array}{l}\text { Product knowledge } \\
\text { and fit between } \\
\text { products }\end{array}$ & Shared view on customer value \\
\hline Pricing activities & $\begin{array}{l}\text { Adapts prices to } \\
\text { suit market } \\
\text { demand }\end{array}$ & $\begin{array}{l}\text { Recommends prices } \\
\text { based on product } \\
\text { costs }\end{array}$ & \\
\hline Marketing activities & $\begin{array}{l}\text { Local customer } \\
\text { demand }\end{array}$ & Product knowledge & Shared view on customer value \\
\hline $\begin{array}{l}\text { Inventory } \\
\text { management } \\
\text { activities }\end{array}$ & & & $\begin{array}{l}\text { Information communication } \\
\text { system }\end{array}$ \\
\hline
\end{tabular}




\section{Managerial implications}

This study describes the resources held by the different category management actors vis-à-vis technical expertise, local customer demand, aggregated-level demand and economies of scale. Even though differences between different kinds of merchants and retailers exist, this description would likely look similar for retailers as well. The description of resource alignment provides support for retailers and their suppliers concerning how to assign category management roles and responsibilities. While the retailers themselves are often well equipped to manage pricing and inventory management, the supplier can provide important support in assortment and marketing management. Another part is the internal coordination between the retailers' central management and the stores, where it is important that the resources of the stores are exploited.

More generally the paper provides management with a matrix that enables management to assess the current status, and required improvements, of resource alignment in category management.

\section{Further research}

In this paper, Das and Teng's (2000) resource framework is applied to explain when and how supplementary resources are needed in order to turn dissimilar resources into performing, complementary resources. It would be interesting to see if these propositions hold in other contexts and can be made into general statements. Though Das and Teng's article is heavily cited, few efforts have been made to apply their framework in empirical settings. The findings in this paper show a possible avenue for further research. The necessity of supplementary resources for obtaining complementary resources requires broader empirical investigation. This paper also demonstrates the potential to analyze category management through the resource alignment framework. The resources identified in this paper apply to builders' merchants, and it would be fruitful to assess whether the resource requirements in other kinds of retailing are similar.

\section{References}

Aastrup, J., D. B. Grant and M. Bjerre. 2007. "Value Creation and Category Management through Retailer-Supplier Relationships." The International Review of Retail, Distribution and Consumer Research 17 (5), 523-541.

Adegbesan, J. A. 2009. "On the Origins of Competitive Advantage: Strategic Factor Markets and Heterogeneous Resource Complementarity." Academy of Management Review 34 (3), 463-475.

Arya, B. and Z. Lin. 2007. "Understanding Collaboration Outcomes from an Extended Resource-Based View Perspective: The Roles of Organizational Characteristics, Partner Attributes, and Network Structures $\uparrow$." Journal of management 33 (5), 697-723. 
Bandyopadhyay, S., A. Rominger and S. Basaviah. 2009. "Developing a Framework to Improve Retail Category Management through Category Captain Arrangements." Journal of Retailing and Consumer Services 16 (4), 315-319.

Basuroy, S., M. K. Mantrala and R. G. Walters. 2001. "The Impact of Category Management on Retailer Prices and Performance: Theory and Evidence." The Journal of Marketing 65 (4), 16-32.

Cachon, G. P. and A. G. Kök. 2007. Category Management and Coordination in Retail Assortment Planning in the Presence of Basket Shopping Consumers. Hanover, MD: Institute for Operations Research and the Management Sciences

Campo, K. and E. Gijsbrechts. 2005. "Retail Assortment, Shelf and Stockout Management: Issues, Interplay and Future Challenges." Applied Stochastic Models in Business and Industry 21 (4-5), 383-392.

Chen, Y., J. D. Hess, R. T. Wilcox and Z. J. Zhang. 1999. "Accounting Profits Versus Marketing Profits: A Relevant Metric for Category Management." Marketing Science 18 (3), 208.

Das, T. K. and B.-S. Teng. 2000. "A Resource-Based Theory of Strategic Alliances." Journal of Management 26 (1), 31-62.

Das, T. K. and B.-S. Teng. 2003. "Partner Analysis and Alliance Performance." Scandinavian Journal of Management 19 (3), 279-308.

Day, G. S. 1994. "The Capabilities of Market-Driven Organizations." Journal of Marketing $58(4), 37-52$.

Desrochers, D. M., G. T. Gundlach and A. A. Foer. 2003. "Analysis of Antitrust Challenges to Category Captain Arrangements." Journal of Public Policy \& Marketing 22 (2), 201215 .

Dhar, S. K., S. J. Hoch and N. Kumar. 2001. "Effective Category Management Depends on the Role of the Category." Journal of Retailing 77 (2), 165-184.

Doh, J. P. 2000. "Entrepreneurial Privatization Strategies: Order of Entry and Local Partner Collaboration as Sources of Competitive Advantage." Academy of Management Review $25(3), 551-571$.

Dupre, K. and T. W. Gruen. 2004. "The Use of Category Management Practices to Obtain a Sustainable Competitive Advantage in the Fast-Moving-Consumer-Goods Industry." Journal of Business \& Industrial Marketing 19 (7), 444-459.

Dussart, C. 1998. "Category Management:: Strengths, Limits and Developments." European Management Journal 16 (1), 50-62. 
Dyer, J. H. and H. Singh. 1998. "The Relational View: Cooperative Strategy and Sources of Interorganizational Competitive Advantage." Academy of Management Review 23 (4), 660-679.

Fawcett, S. E. and G. M. Magnan. 2001. Achieving World-Class Supply Chain Alignment: Benefits, Barriers, and Bridges. Center for Advanced Purchasing Studies Tempe, AZ

Gooner, R. A., N. A. Morgan and W. D. Perreault. 2011. "Is Retail Category Management Worth the Effort (and Does a Category Captain Help or Hinder)?" Journal of Marketing 75 (5), 18-33.

Grant, R. M. and C. Baden-Fuller. 2004. "A Knowledge Accessing Theory of Strategic Alliances." Journal of Management Studies 41 (1), 61-84.

Gruen, T. W. and R. H. Shah. 2000. "Determinants and Outcomes of Plan Objectivity and Implementation in Category Management Relationships." Journal of Retailing 76 (4), 483.

Gulati, R., N. Nohria and A. Zaheer. 2000. "Strategic Networks." Strategic Management Journal 21 (3), 203-215.

Harris, B. and M. McPartland. 1993. "Category Management Defined: What It Is and Why It Works." Progressive Grocer 72 (9), 5.

Harrison, J. S., M. A. Hitt, R. E. Hoskisson and R. D. Ireland. 1991. "Synergies and PostAcquisition Performance: Differences Versus Similarities in Resource Allocations." Journal of Management 17 (1), 173.

Harrison, J. S., M. A. Hitt, R. E. Hoskisson and R. D. Ireland. 2001. "Resource Complementarity in Business Combinations: Extending the Logic to Organizational Alliances." Journal of Management 27 (6), 679-690.

Hitt, M. A., M. T. Dacin, E. Levitas, J. L. Arregle and A. Borza. 2000. "Partner Selection in Emerging and Developed Market Contexts: Resource-Based and Organizational Learning Perspectives." Academy of Management Journal 43 (3), 449-467.

Holweg, C., P. Schnedlitz and C. Teller. 2009. "The Drivers of Consumer Value in the Ecr Category Management Model." The International Review of Retail, Distribution and Consumer Research 19 (3), 199-218.

Hübner, A. H. and H. Kuhn. 2012. "Retail Category Management: State-of-the-Art Review of Quantitative Research and Software Applications in Assortment and Shelf Space Management." Omega 40 (2), 199-209.

Håkansson, H. and I. Snehota. 1989. "No Business Is an Island: The Network Concept of Business Strategy." Scandinavian Journal of Management 5 (3), 187-200.

Ireland, R. D., M. A. Hitt and D. Vaidyanath. 2002. "Alliance Management as a Source of Competitive Advantage." Journal of management 28 (3), 413-446. 
Kurtulus, M. and B. Toktay. 2005. "Category Captainship: Who Wins Who Loses?" Available at SSRN 934970

Kurtuluş, M. and L. B. Toktay. 2011. "Category Captainship Vs. Retailer Category Management under Limited Retail Shelf Space." Production and Operations Management 20 (1), 47-56.

Kurtuluş, M., S. Ülkü, J. P. Dotson and A. Nakkas. 2014. "The Impact of Category Captainship on the Breadth and Appeal of a Retailer's Assortment." Journal of Retailing 90 (3), 379-392.

Lambe, C. J., R. E. Spekman and S. D. Hunt. 2002. "Alliance Competence, Resources, and Alliance Success: Conceptualization, Measurement, and Initial Test." Journal of the Academy of Marketing Science 30 (2), 141-158.

Larson, R. 2005. "Making Category Management More Practical." Journal of Food Distribution Research 36 (1), 101-105.

Lin, Z., H. Yang and B. Arya. 2009. "Alliance Partners and Firm Performance: Resource Complementarity and Status Association." Strategic Management Journal 30 (9), 921940.

Lindblom, A., R. Olkkonen, P. Ollila and S. Hyvönen. 2009. "Suppliers' Roles in Category Management: A Study of Supplier-Retailer Relationships in Finland and Sweden." Industrial Marketing Management 38 (8), 1006-1013.

Mathews, J. A. 2003. "Competitive Dynamics and Economic Learning: An Extended Resource-Based View." Industrial and Corporate Change 12 (1), 115-145.

Morgan, R. M. and S. D. Hunt. 1994. "The Commitment-Trust Theory of Relationship Marketing." Journal of Marketing 58 (3), 20-38.

Narasimhan, R. and S. W. Kim. 2002. "Effect of Supply Chain Integration on the Relationship between Diversification and Performance: Evidence from Japanese and Korean Firms." Journal of Operations Management 20 (3), 303-323.

Song, M., C. Droge, S. Hanvanich and R. Calantone. 2005. "Marketing and Technology Resource Complementarity: An Analysis of Their Interaction Effect in Two Environmental Contexts." Strategic Management Journal 26 (3), 259-276.

Squire, B., P. D. Cousins and S. Brown. 2006. "Collaborating for Customisation: An Extended Resource-Based View of the Firm." International Journal of Productivity and Quality Management 1 (1), 8-25.

Squire, B., P. D. Cousins, B. Lawson and S. Brown. 2009. "The Effect of Supplier Manufacturing Capabilities on Buyer Responsiveness: The Role of Collaboration." International Journal of Operations \& Production Management 29 (8), 766-788. 
Stuart, T. E. 2000. "Interorganizational Alliances and the Performance of Firms: A Study of Growth and Innovation Rates in a High-Technology Industry." Strategic Management Journal 21 (8), 791-811.

Subramanian, U., J. S. Raju, S. K. Dhar and Y. Wang. 2010. "Competitive Consequences of Using a Category Captain." Management Science 56 (10), 1739-1765.

van der Vaart, T. and D. P. van Donk. 2008. "A Critical Review of Survey-Based Research in Supply Chain Integration." International Journal of Production Economics 111 (1), 4255 .

Wang, L. and E. J. Zajac. 2007. "Alliance or Acquisition? A Dyadic Perspective on Interfirm Resource Combinations." Strategic Management Journal 28 (13), 1291-1317.

Williamson, O. E. 1991. "Comparative Economic Organization: The Analysis of Discrete Structural Alternatives." Administrative Science Quarterly 36 (2), 269-296.

Wittmann, C. M., S. D. Hunt and D. B. Arnett. 2009. "Explaining Alliance Success: Competences, Resources, Relational Factors, and Resource-Advantage Theory." Industrial Marketing Management 38 (7), 743-756. 